\title{
Comprehensive evaluation of long term trends in occupational exposure: part 1. Description of the database
}

Elaine Symanski, Lawrence L Kupper, Stephen M Rappaport

\begin{abstract}
Objectives-To conduct a comprehensive evaluation of long term changes in occupational exposure among a broad cross section of industries worldwide.

Methods-A review of the scientific literature identified studies that reported historical changes in exposure. About 700 sets of data from 119 published and several unpublished sources were compiled. Data were published over a 30 year period in 25 journals that spanned a range of disciplines. For each data set, the average exposure level was compiled for each period and details on the contaminant, the industry and location, changes in the threshold limit value (TLV), as well as the type of sampling method were recorded. Spearman rank correlation coefficients were used to identify monotonic changes in exposure over time and simple linear regression analyses were used to characterise trends in exposure.
\end{abstract}

Results-About $78 \%$ of the natural log transformed data showed linear trends towards lower exposure levels whereas $22 \%$ indicated increasing trends. (The Spearman rank correlation analyses produced a similar breakdown between exposures monotonically increasing or decreasing over time.) Although the rates of reduction for the data showing downward trends ranged from $-1 \%$ to $-62 \%$ per year, most exposures declined at rates between $-4 \%$ and $-14 \%$ per year (the interquartile range), with a median value of $-\mathbf{8 \%}$ per year. Exposures seemed to increase at rates that were slightly lower than those of exposures which have declined over time. Data sets that showed downward (versus upward) trends were influenced by several factors including type and carcinogenicity of the contaminant, type of monitoring, historical changes in the threshold limit values (TLVs), and period of sampling.

Conclusions-This review supports the notion that occupational exposures are generally lower today than they were years or decades ago. However, such trends seem to have been affected by factors related to the contaminant, as well as to the period and type of sampling.

(Occup Environ Med 1998;55:300-309)

Keywords: occupational exposure; exposure assessment; long term trends
It is generally recognised that levels of airborne contaminants in occupational settings change over time due to a host of factors. ${ }^{1-6}$ As these factors tend to systematically influence the process giving rise to exposure, the underlying distribution of exposures may no longer be characterised by a mean value independent of time. In this instance, the distribution is said to be non-stationary. ${ }^{7}$ As many conventional statistical methods are based on the assumption that the parameters of the underlying exposure distribution do not change over time, the failure to recognise non-stationary behaviour may compromise our ability to assess exposures accurately. ${ }^{6}$

Several different workplace conditions can give rise to non-stationary exposure distributions. For example, concentrations in air may steadily rise during start up operations or during periods of increased rates of production, or, conversely, may fall as output diminishes due to such economic factors as downsizing or reduced demand. Changes to the process, the installation of new control equipment, or the introduction of improved work practices should also lower exposures. Thus altogether, it would be anticipated that long term trends would be towards lower exposures, except for periods of heightened activity due to economic growth or start up operations. Moreover, the continuous lowering of exposure limits for many air contaminants provides additional, albeit indirect, evidence that exposures have generally been declining over time. ${ }^{8}$

Although occupational exposure levels are likely to have changed over time, relatively few studies have been conducted to investigate the long term behaviour of exposure. ${ }^{9-14}$ More often, evidence of systematic changes in exposure is found in studies designed for other purposes - such as for reconstructing historical exposures as part of epidemiological investigations or for examining the relation between air and biological monitoring. As these investigations are reported in publications covering a wide range of disciplines, it becomes problematic to identify those that characterise long term exposures. As a result, it is difficult to support general statements about temporal trends in concentrations of airborne contaminants.

In the light of a lack of understanding of the historical behaviour of occupational exposures, we undertook a comprehensive evaluation of long term changes in exposure among a broad cross section of industries. Our primary aim was to review the scientific literature, identify 
Table 1 Breakdown (number of data sets) of industries, by type of contaminant, for aerosols represented in the database

\begin{tabular}{|c|c|}
\hline Aluminum fluoride: & Lead (continued): \\
\hline Aluminum fluoride production (1) & Foundries (8) \\
\hline Asbestos: & Lead smelting (4) \\
\hline Asbestos cement production (9) & Metal scrap industry (1) \\
\hline Asbestos milling (2) & Metal producing plants (2) \\
\hline Asbestos mining (4) & Motor car repair shops (2) \\
\hline Asbestos textile production (16) & Polyvinyl chloride plastics industry (1) \\
\hline Vermiculite mining and milling (2) & Railroad machine shops (1) \\
\hline Arsenic: & Sonar equipment manufacturing (1) \\
\hline Copper smelter (25) & Machining fluid: \\
\hline Decorative glassware manufacturing (2) & Automotive plants (3) \\
\hline Benzene-soluble fraction of total particulates: & Manganese: \\
\hline Steel plant (1) & Manganese ore milling (1) \\
\hline Beryllium: & MBOCA: \\
\hline Beryllium extraction and manufacturing (16) & Polyurethane plastics (1) \\
\hline Cadmium: & Nickel: \\
\hline Battery manufacturing (4) & Copper refining (9) \\
\hline Cadmium production (9) & Nickel alloy manufacturing (3) \\
\hline Cd pigment production $(1)$ & Nickel mining (3) \\
\hline Cd alloy manufacturing (4) & Nickel milling (16) \\
\hline Zinc processing plants $(2)$ & Nickel smelting (34) \\
\hline Chromium: & Nickel refining (80) \\
\hline Chomeplating industry (1) & Nickel oxides: \\
\hline Coal dust: & Nickel smelting (5) \\
\hline Coal mining (35) & Nickel sulphides: \\
\hline Cobalt: & Nickel refining (3) \\
\hline Porcelain factories (1) & Nitrate esters: \\
\hline Dusts: & Dynamite manufacturing (4) \\
\hline Aluminum production (5) & Nitrate fertiliser plant (4) \\
\hline Cement production (8) & Polynuclear aromatic hydrocarbons: \\
\hline Flax mills (15) & Needle coke manufacturing (2) \\
\hline Grain elevators (1) & Silica: \\
\hline Granite sheds (9) & Coal mining (7) \\
\hline Haematite iron ore mining (1) & Copper mining (1) \\
\hline Nitrate-fertiliser manufacturing (2) & Pottery making (15) \\
\hline Sulphur, cobalt, zinc plants (4) & Mining of metal ores (65) \\
\hline Talc milling (12) & Sulphuric acid: \\
\hline Talc mining $(6)$ & Battery factories (2) \\
\hline Vermiculite milling (2) & Galvanising factories (2) \\
\hline Fluorides (mixed exposure, predominantly particulate): & Thallium: \\
\hline Aluminum smelter (1) & Alloy anode plate manufacturing (1) \\
\hline Aluminum production (11) & Trichlorfon: \\
\hline Hydroquinone: & Pesticide production (1) \\
\hline Hydroquinone manufacturing (1) & Trimellitic anhydride: \\
\hline Lead: & Plastics, epoxy resins, and paint manufacturing (3) \\
\hline Ammunition manufacture (2) & Trinitrotoluene (mixed exposure, predominantly particulate): \\
\hline Automotive assembly (3) & Munitions plant (2) \\
\hline Battery manufacturing (21) & Uranium: \\
\hline Chemicals manufacturing (1) & Uranium milling (1) \\
\hline Crystal glass industry (1) & \\
\hline
\end{tabular}

studies that reported historical changes in exposure, and compile the exposure data reported therein. We then wanted to measure changes in exposure, determine whether consistent trends have occurred industry wide, and explain why some exposures have changed more than others. This paper describes our review of the literature and measurement of temporal effects; an accompanying $\operatorname{article}^{15}$ focuses on our assessment of factors which influenced changes in exposure over time.

\section{Methods}

COMPILATION OF THE DATABASE

The scientific literature, primarily in the fields of occupational hygiene and occupational epidemiology, was reviewed to identify studies that reported historical occupational exposures. Two databases available from other investigations, one of chemical exposures from various industries worldwide, ${ }^{16}$ and the other of nickel exposures derived exclusively from industrial sources, were also accessed to identify data suitable for analysis. At least three average exposure levels (estimated from area, personal, or biological monitoring data) had to be reported over a period of three years or longer. Data presented either in tabular or graphical form were used after being abstracted as they were reported (including any transformation performed by the original authors-for example, conversion from particle number concentrations to mass units). The midpoint of the sampling interval was computed when mean exposure levels had been averaged over periods extending for two or more years. In studies presenting both arithmetic and geometric mean (median) exposures, arithmetic means were used. If an investigator had published more than one study with the same set of data, only one was included in the database.

As well as compiling average exposure levels by period for each data set, details on the source and type of contaminant, along with features of the sampling regimen, were recorded. The United Nations international standard industrial classification (ISIC) of all economic activities was used to assign industrial codes. ${ }^{17}$ The countries in which the data had been collected were identified. The International Agency for Research on Cancer (IARC) system of classification was used to group contaminants according to their carcinogenicity. ${ }^{18-24}$ Also, IARC classification during the period over which the data were collected was compiled. ${ }^{25-30}$ Information about the type of monitoring (biological, area, or 
Table 2 Breakdown (number of data sets) of industries, by type of contaminant, for gases and vapours represented in the database ${ }^{\star}$

Acetone:

Automotive assembly (1)

Cellulose acetate yarn manufacturing (1)

Allyl chloride:

Organochlorine production (1)

1,3-dichloropropene:

Organochlorine production Benzene:

Petroleum refining (16)

p-Benzoquinone:

Hydroquinone manufacturing (1)

Bis-chloromethyl ether:

Anion exchange manufacturing plant (1)

1,3-Dichloropropene:

Organochlorine production (1)

$\mathrm{N}, \mathrm{N}$-dimethlyformamide:

Urethane resin manufacturing (1)

Carbon disulphide:

Rayon filament and $\mathrm{CS}_{2}$ production (6)

Viscose rayon industry (7)

Carbon disulphide and hydrogen sulphide:

Carbon disulphfide factory (1)

Viscose film factories (3)

Viscose rayon factories (8)

Epichlorohydrin:

Organochlorine plant (1)

Ethylene oxide:

Plant producing medical equipment (2)

Formaldehyde:

Furniture manufacturing (1)

Urea formaldehyde resin manufacturing (1)

Hexachlorobenzene:

Chlorinated solvents manufacturing (1)

Hexachloropentadiene:

Organochlorine plant (1)

Hydrogen chloride:

Chemical manufacturing plant (2)

Isocyanates (toluene diisocyanates or diphenyl methane isocyanates):

Automobile parts manufacturing (4)

Isopropyl alcohol:

Automotive assembly (1)

Isopropyl biphenyls:

Capacitor manufacturing (3)

Mercury vapour:

Chloralkali industry (2)

Fluorescent lamp factory (2)

Methyl methacrylate:

Acrylic fibre manufacturing (1)

Chemical manufacturing (1)

Methylene chloride:

Film manufacturing plant (1)

Mineral spirits:

Painting shops (4)

Nitrogen dioxide:

Fertiliser manufacturing (1)

Organic vapour:

Pesticide manufacturing (3)

Petroleum distillates:

Automotive assembly (1)

Piperazine:

Chemical manufacturing (2)

Solvents:

Furniture manufacturing (1)

Styrene:

Automotive assembly (1)

Chemical manufacturing (1)

Reinforced boat manufacturing (1)

Wholesale and commission trade (1)

Sulphur dioxide:

Copper smelter (6)

Pulp and paper mill (2)

Sulphur, cobalt, zinc plants (4)

Tetrachlorethylene:

Automotive assembly (1)

Toluene:

Automotive industry (1)

Painting shops (5)

Photogravure printing (2)

1,1,1,-Trichlorethane:

Automotive assembly (1)

Trichloroethylene:

Automotive industry (1)

Vinyl chloride:

Polyvinyl chloride plants (5)

VM and P Naptha:

Automotive assembly (1)

Xylenes:

Painting shops (5)
Rubber hydrochloride manufacturing (17)

${ }^{\star}$ Data sets averaging exposure levels across industries are not tabulated

personal sampling) was recorded. Short term personal samples collected in the breathing zone were distinguished from shift long personal samples. Data on the aggregation of exposure levels (by job group or work area, by factory or plant, across factories, or across industries) were compiled as well. If provided, any information about changes in sampling or analytical methods during the period monitored was noted. To assess time dependent effects, data were stratified into three periods based on the period of sampling - that is, up to and including 1972, both before and after 1972 , or from 1972 onwards. To evaluate the possibility of a relation between trends toward lower air contaminant levels and the reduction of exposure limits over time, historical changes in the threshold limit values (TLVs) recommended by the American Conference of Governmental Industrial Hygienists (ACGIH) were recorded over the period during which each set of data had been collected..$^{32}$

Finally, as some studies summarised exposures with both biological and airborne monitoring data, reported both personal and area monitoring results, or averaged the data in more than one way-for example, by job group and across job groups - a variable was coded to identify duplicated data. Occasionally, different investigators used the same set of data in their studies. These duplicates were identified whenever possible and were omitted in all analyses.
Table 3 Breakdown of the database by selected characteristics related to the contaminant or to the sampling regimen ( $n=696$ data sets)

\begin{tabular}{|c|c|c|}
\hline Factor & $n$ & $\%$ * \\
\hline \multicolumn{3}{|l|}{ Region: } \\
\hline Western Europe & 251 & 36 \\
\hline North America & 289 & 42 \\
\hline Japan & 23 & 3 \\
\hline Eastern Europe & 10 & 1 \\
\hline Other & 123 & 18 \\
\hline \multicolumn{3}{|l|}{ Industry: } \\
\hline Manufacturing & 523 & 75 \\
\hline Mining and quarrying & 163 & 23 \\
\hline Other & 10 & 1 \\
\hline \multicolumn{3}{|l|}{ Type of contaminant: } \\
\hline Vapours & 170 & 24 \\
\hline Non-metallic aerosols & 256 & 37 \\
\hline Metals and metalloids & 270 & 39 \\
\hline \multicolumn{3}{|l|}{ Carcinogenicity†: } \\
\hline 1 & 320 & 46 \\
\hline $2 \mathrm{~A}$ & 100 & 14 \\
\hline $2 \mathrm{~B}$ & 79 & 11 \\
\hline 3 & 30 & 4 \\
\hline Not classified & 167 & 24 \\
\hline \multicolumn{3}{|l|}{ Type of monitoring: } \\
\hline Personal & 309 & 44 \\
\hline Stationary & 253 & 36 \\
\hline Personal and stationary & 41 & 6 \\
\hline Biological & 93 & 13 \\
\hline \multicolumn{3}{|l|}{ Mean exposure levels: } \\
\hline By job group or work area & 436 & 63 \\
\hline By plant or factory & 105 & 15 \\
\hline Across factories & 147 & 21 \\
\hline Across industries & 8 & 1 \\
\hline \multicolumn{3}{|l|}{ Period of sampling: } \\
\hline Before 1972 & 83 & 12 \\
\hline Before and after 1972 & 269 & 39 \\
\hline From 1972 onwards & 344 & 49 \\
\hline \multicolumn{3}{|l|}{ Observations (n): } \\
\hline $3-4$ & 294 & 42 \\
\hline $5-10$ & 256 & 37 \\
\hline $11-51$ & 146 & 21 \\
\hline \multicolumn{3}{|l|}{ Duration of sampling (y): } \\
\hline$\leqslant 5$ & 125 & 18 \\
\hline $6-10$ & 163 & 23 \\
\hline $11-20$ & 200 & 29 \\
\hline$\geqslant 21$ & 208 & 30 \\
\hline \multicolumn{3}{|l|}{ TLV $\ddagger$ reductions (n): } \\
\hline 0 & 361 & 52 \\
\hline 1 & 166 & 24 \\
\hline 2 & 162 & 23 \\
\hline 3 & 7 & 1 \\
\hline
\end{tabular}

*Percentages may not add up to 100 due to rounding. †Based on the most recent IARC classification of contaminants. $\ddagger T L V=$ threshold limit value of the American Conference of Governmental Industrial Hygienists (ACGIH).

When selecting data sets to include, preference was given to airborne monitoring data, personal sampling results, and to data averaged over the smallest possible group of workers.

ANALYSIS OF TEMPORAL CHANGES IN EXPOSURE Scatter plots of exposure levels and their natural logarithms over time were generated. For each data set, the non-parametric Spearman rank correlation coefficient was calculated to assess whether there was any evidence of a monotonic change in exposure over time. As linear trends in the log transformed values of exposure levels over time have been found in several previous investigations, ${ }^{33-35}$ a simple regression of the logged exposure data on time was carried out. The model can be expressed as follows:

$$
\mathrm{E}\left(\mathrm{Y}_{\mathrm{it}_{\mathrm{ij}}}\right)=\mathrm{E}\left(\ln \mathrm{X}_{\mathrm{it}_{\mathrm{ij}}}\right)=\alpha_{\mathrm{i}}+\beta_{\mathrm{i}} \mathrm{t}_{\mathrm{ij}}
$$

for $\mathrm{i}=1,2, \ldots, \mathrm{n}$ data sets and where $\mathrm{t}_{\mathrm{ij}}$ is the $j$-th timepoint for the $i$-th data set, $j=1,2, \ldots, n_{i}$. Note that the time points are not necessarily evenly spaced and are indexed by $i$ indicating that each data set may vary in terms of the 

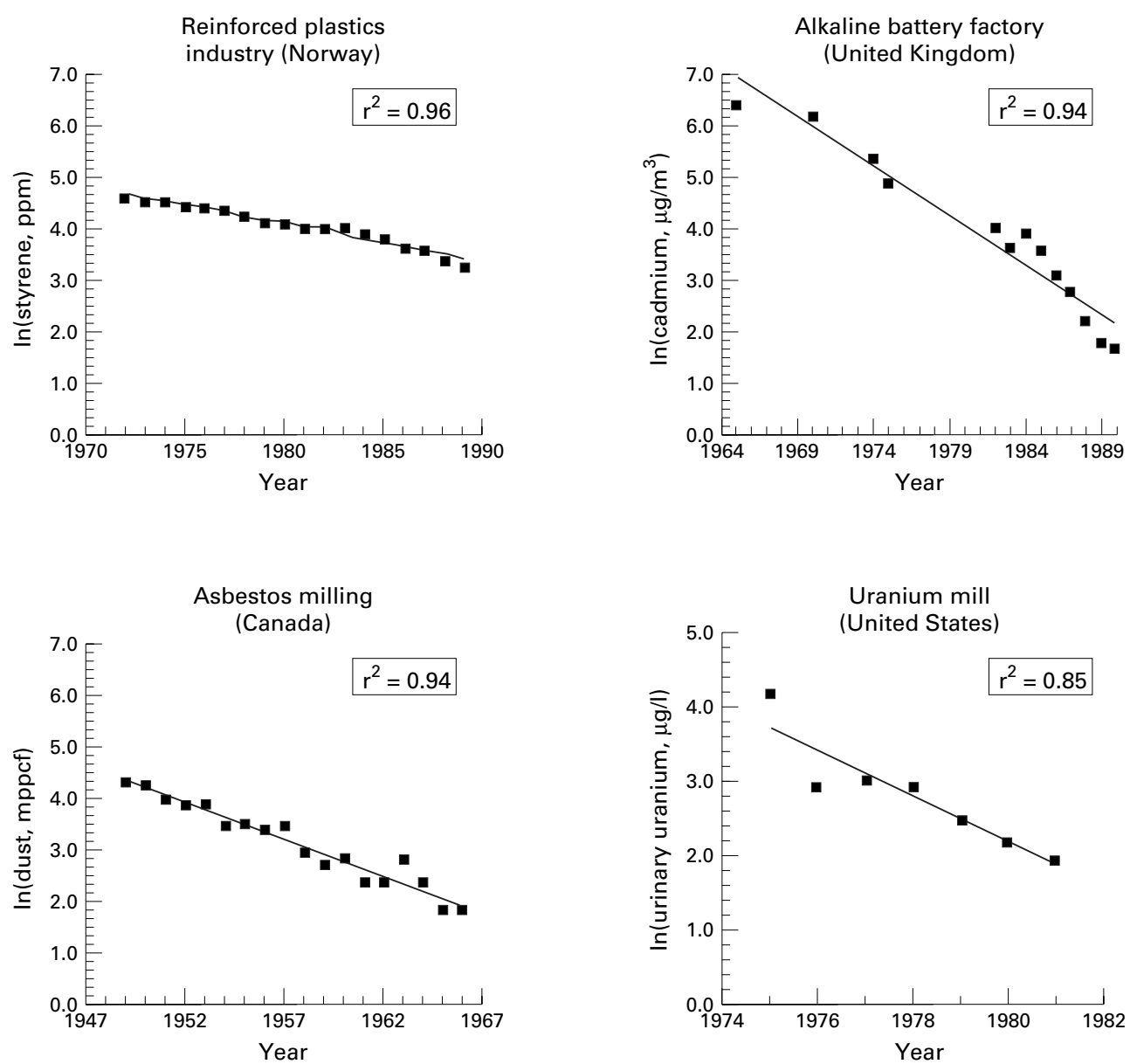

Figure 1 Examples of declining exposures to styrene in the reinforced plastics industry, ${ }^{84}$ dust in asbestos milling, ${ }^{37}$ cadmium in a battery factory, ${ }^{34}$ and uranium as measured in the urine of workers at a uranium mill. ${ }^{55}$

number of occasions at which exposure levels had been evaluated. Here, $\mathrm{X}_{\mathrm{it}_{\mathrm{ij}}}$ represents the mean exposure level for data set $i$ at time point $t_{i j}, Y_{i t_{i j}}$ is the natural logarithm of the exposure level for data set $i$ at time point $t_{i j}, \alpha_{i}$ is the intercept term, and $\beta_{i}$ is the regression coefficient associated with time for the i-th data set.

The unweighted least squares slope estimate $\left(\hat{\beta}_{\mathrm{i}}\right)$ was then used to compute the quantity $100\left(\hat{\theta}_{\mathrm{i}}\right)$, the estimated median percentage change in exposure per year, where $\hat{\theta}_{\mathrm{i}}=\left(\mathrm{e}^{\hat{\beta}_{\mathrm{i}}}-1\right)$. The theory supporting the use of $\hat{\theta}_{\mathrm{i}}$ is presented in the appendix. (In cases in which monthly data were recorded over periods of several years, the slope estimate was first multiplied by a factor of 12 to obtain the corresponding annual value.) Note that the regression model assumes a fixed percentage increase $\left(\beta_{\mathrm{i}}>0\right)$ or decrease $\left(\beta_{\mathrm{i}}<0\right)$ in the exposure level from one year to the next. Correlation and regression analyses were performed with SAS procedures (SAS Institute, Cary, NC). Although we largely report our findings on the basis of whether the trend estimates were positive or negative, results evaluated at a significance level of 0.05 are summarised as well.

EVALUATION OF MULTIPLE COMPARISON ISSUES The issue of multiple testing was considered in two ways. Firstly, we examined our overall findings by using a $\chi^{2}$ test to evaluate the likeli- hood of obtaining the observed proportion of data with negative trends assuming that exposure levels had not changed over timethat is, under the null hypothesis that there was an equally likely chance of obtaining either a negative or positive estimated trend result for each of the $n$ data sets. Secondly, given that $n$ independent regression analyses were examined for significance $(\mathrm{p}<0.05)$ under the null hypothesis that exposure levels remained the same over time, the expected number of significant results if all $\mathrm{n}$ of the individual null hypotheses were true (namely, 0.05n) was compared with the observed number of data sets with significant trends.

\section{Results}

\section{CHARACTERISTICS OF THE DATABASE}

In total, 119 studies that reported exposure levels over time were identified, along with several sources of unpublished data. In many cases, more than one set of data was available within an individual study, so that a total number of 696 data sets were compiled. Data were found in 25 journals that spanned a broad range of disciplines, including occupational hygiene, epidemiology, medicine, environmental health, and toxicology. Although most studies (71\%) were published in epidemiological or medical journals, relatively few $(11 \%)$ came from the classic occupational hygiene literature. Taken 
together, the studies were published over almost a 30 year period, with the earliest paper appearing in 1967 and the latest in 1996.

Tables 1 and 2 show that the database represents a broad range of exposures to both aerosols and vapours arising in various different industries. Although most studies focused on investigations of workplaces in North America, ${ }^{33}{ }^{35-70}$ the United Kingdom, ${ }^{34}$ 71-84 and in Scandinavia, ${ }^{2}{ }^{1012-14}$ 84-112 other countries were also represented-namely, Czechoslovakia, ${ }^{113} 114$ France, ${ }^{115}$ Germany, ${ }^{22} 116$ Italy, ${ }^{84}{ }^{117-122}$ the Netherlands, ${ }^{123-126}$ Poland, ${ }^{127}$ Romania, ${ }^{128}$ Japan, ${ }^{129-133}$ China, ${ }^{134-140}$ Singapore, ${ }^{141}$ Greenland, ${ }^{142}$ Israel, ${ }^{143}$ South Africa, ${ }^{144}$ and Australia (unpublished data). Table 3 summarises characteristics related to the source and type of contaminant represented by the data ( $n=696$ data sets).

ANALYSIS OF TEMPORAL CHANGES IN EXPOSURE

Based on results from the Spearman rank correlation analyses, $76 \%$ of the data showed evidence of a decreasing monotonic change in exposure over time $\left(r_{S}<0\right), 23 \%$ indicated increasing exposures $\left(r_{S}>0\right)$, and few $(1 \%)$ showed no change in either direction $\left(r_{S}=0\right)$. The linear regression analyses produced similar results with $78 \%$ of the logged data indicating trends towards lower exposure levels (Pearson's $r<0$ ). For the group of declining exposures, strong correlations were found with a median Spearman correlation coefficient of -0.80 (median Pearson's $r=-0.80$ ). On the other hand, increasing exposures showed, on average, much lower correlations with a median Spearman correlation coefficient of 0.37 (median Pearson's $r=0.34$ ).

Linear regressions of the logged exposures over time generally showed evidence of temporal effects on exposure levels, sometimes with clear decreasing linear trends of the logged data over time. Figure 1 shows this for styrene in the reinforced plastics industry, ${ }^{84}$ dust in asbestos milling, ${ }^{37}$ cadmium in a battery factory, ${ }^{34}$ and uranium as measured in the urine among workers at a uranium mill. ${ }^{55}$ Overall, the median $r^{2}$ value for data sets with declining trends was 0.65 ; the corresponding value for increasing exposures was 0.11 .

Table 4 compares the results from the linear regression analyses stratified by various factors related to the contaminant or to the type of sampling performed. Our results suggest that the breakdown by geographical region, industrial sector, and type of contaminant was relatively similar for both downward and increasing exposures. On the other hand, $31 \%$ of the exposures evaluated by personal monitoring had increased over time compared with $14 \%$ of the biological monitoring data. Although the differences were not large, a greater percentage of carcinogens (designated as class $1,2 \mathrm{~A}$, or $2 \mathrm{~B}$ by IARC during the sampling period) (26\%) increased over time compared with noncarcinogens $(17 \%)$. When comparing the group of data collected before 1972 with those exposures evaluated after 1972, a larger proportion of the later data was characterised by increasing exposures ( $8 \%$ versus $31 \%$ ).
Table 4 Breakdown (\%) of the trend results stratified by characteristics related to the contaminant or to the sampling regimen

\begin{tabular}{|c|c|c|}
\hline & $\begin{array}{l}\text { Downwward trend } \\
\text { ( } 543 \text { data sets) }\end{array}$ & $\begin{array}{l}\text { Upward trend } \\
\text { (153 data sets) }\end{array}$ \\
\hline \multicolumn{3}{|l|}{ Region: } \\
\hline Western Europe & $202(80)$ & $49(20)$ \\
\hline North America & $225(78)$ & $64(22)$ \\
\hline Japan & $17(74)$ & $6(26)$ \\
\hline Eastern Europe & $10(100)$ & - \\
\hline Other & $89(72)$ & $34(28)$ \\
\hline \multicolumn{3}{|l|}{ Industry: } \\
\hline Manufacturing & $402(77)$ & $121(23)$ \\
\hline Mining and quarrying & $133(82)$ & $30(18)$ \\
\hline Other & $8(80)$ & $2(20)$ \\
\hline \multicolumn{3}{|l|}{ Type of contaminant: } \\
\hline Vapour & $135(79)$ & $35(21)$ \\
\hline Non-metallic aerosol & $211(82)$ & $45(18)$ \\
\hline Metal or metalloid & $197(73)$ & $73(27)$ \\
\hline \multicolumn{3}{|l|}{ Carcinogenicity*: } \\
\hline Carcinogen & $269(74)$ & $95(26)$ \\
\hline Non-carcinogen & $274(83)$ & $58(17)$ \\
\hline \multicolumn{3}{|l|}{ Type of monitoring: } \\
\hline Biological & $80(86)$ & $13(14)$ \\
\hline Personal & $213(69)$ & $96(31)$ \\
\hline Area & $210(83)$ & $43(17)$ \\
\hline Area and personal & $40(98)$ & $1(2)$ \\
\hline \multicolumn{3}{|l|}{$\begin{array}{l}\text { Exposure levels: } \\
\text { : }\end{array}$} \\
\hline By job group or work area & $334(77)$ & $102(23)$ \\
\hline By factory & $84(80)$ & $21(20)$ \\
\hline Across factories & $119(81)$ & $28(19)$ \\
\hline Across industries & $6(75)$ & $2(25)$ \\
\hline \multicolumn{3}{|l|}{ Period of sampling: } \\
\hline Up to and including 1972 & $76(92)$ & $7(8)$ \\
\hline Before and after 1972 & $229(85)$ & $40(15)$ \\
\hline From 1972 onwards & $238(69)$ & $106(31)$ \\
\hline \multicolumn{3}{|l|}{ Observations (n): } \\
\hline $3-4$ & $248(84)$ & $46(16)$ \\
\hline $5-10$ & $192(75)$ & $64(25)$ \\
\hline & $103(71)$ & $43(29)$ \\
\hline \multicolumn{3}{|l|}{ Duration of sampling $(\mathrm{y})$ : } \\
\hline$\leqslant 5$ & $85(68)$ & $40(32)$ \\
\hline $6-10$ & $122(75)$ & $41(25)$ \\
\hline $11-20$ & $147(75)$ & $53(25)$ \\
\hline$\geqslant 21$ & $189(91)$ & $19(9)$ \\
\hline \multicolumn{3}{|l|}{ TLV $†$ reductions $(\mathrm{n})$ : } \\
\hline Zero & $253(70)$ & $108(30)$ \\
\hline One & $134(81)$ & $32(19)$ \\
\hline Two or three & $156(92)$ & $13(8)$ \\
\hline
\end{tabular}

${ }^{\star}$ Classified as a carcinogen if IARC designated the contaminant as a class $1,2 \mathrm{~A}$, or $2 \mathrm{~B}$ carcinogen by the end of the sampling period.

$+T L V=$ threshold limit value of the American Conference of Governmental Industrial Hygienists (ACGIH)

Table 4 also provides a breakdown by duration of sampling, sample size, and the number of reductions in the TLV that took place during the sampling period.

Figure 2 A shows a cumulative frequency distribution of the rates of change in exposure for the entire set of data $(n=696)$. The rates ranged from $-62 \%$ to $+121 \%$, with values of $-1 \%,-6 \%$, and $-11 \%$ per year for the 25 th, 50th, and 75th percentiles, respectively. Figure $2 \mathrm{~B}$ shows the cumulative frequency distribution of the data showing downward trends in exposure $(n=543)$. The rates of reduction ranged from $-1 \%$ to $-62 \%$ per year. However, most exposures declined at rates between $-4 \%$ and $-14 \%$ per year (the interquartile range), with a median value of $-8 \%$ per year. The 25 th, 50 th, and 75 th percentiles for those data with significantly negative trends $(\mathrm{p}<0.05)$ were $-6 \%,-9 \%$, and $-17 \%$ per year $(n=202$, data not shown). Finally, for the data sets showing upward trends $(n=153)$, the 25th, 50th, and 75 th percentiles were $+2 \%,+6 \%$, and $+12 \%$ per year (fig $2 \mathrm{C}$ ). (Of these data, only 13 data sets produced significantly positive trends $(\mathrm{p}<0.05))$. 

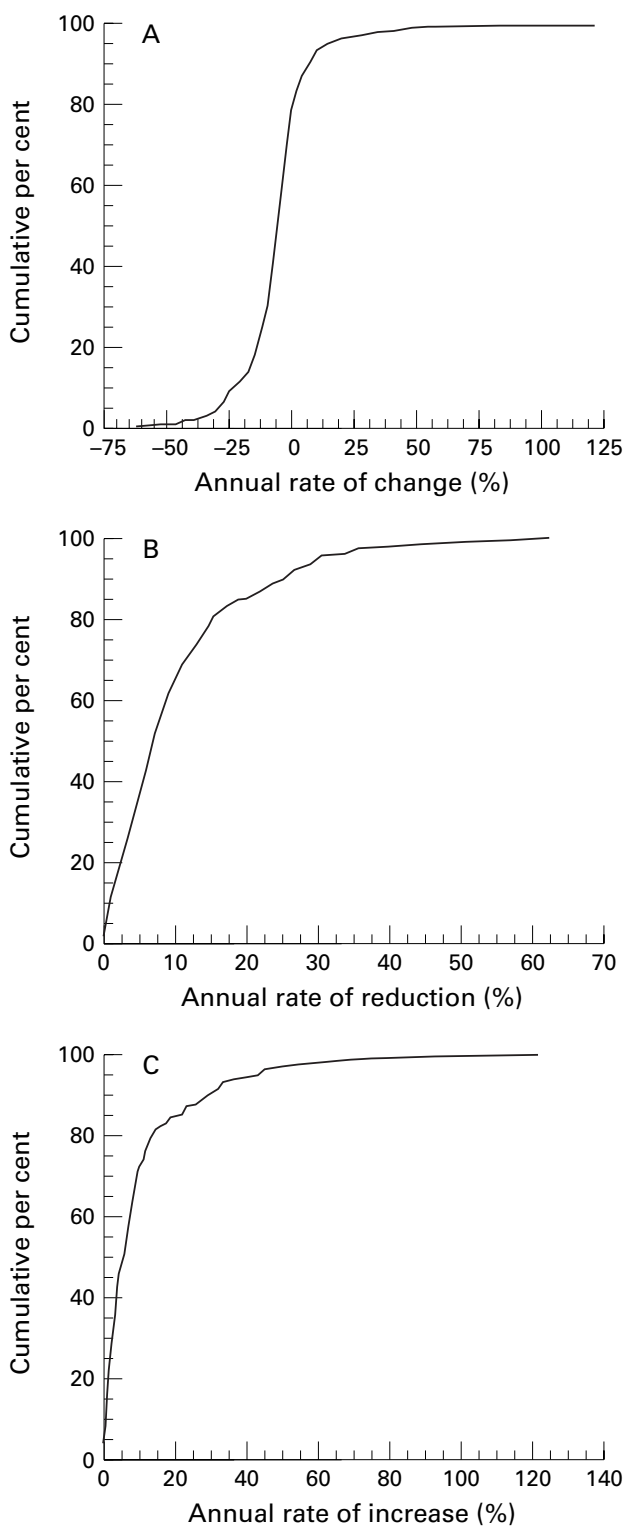

Figure 2 Cumulative frequency distributions of the rates of change for $(A)$ decreasing and increasing trends $(n=696),(B)$ decreasing trends $(n=543)$, and $(C)$ increasing trends $(n=153)$.

EVALUATION OF MULTIPLE COMPARISON ISSUES The $\chi^{2}$ test compared the observed proportion of the 696 data sets with negative trends (namely, $0.78=543 / 696$ ) with the null value of 0.50 , and was highly significant. Secondly, under the null hypothesis that exposures had not changed, we would expect, on average, about 35 of the 696 regression analyses to be significant when each regression is evaluated at a significance level of 0.05 . We found that 215 (many more than 35) data sets had either significantly negative $(n=202)$ or significantly positive $(n=13)$ trends. These results make it clear that our findings are not attributable to chance and that issues related to multiple comparisons have not contaminated our conclusions.

\section{Discussion}

Despite the widespread belief that exposures are generally lower today than they were years or decades ago, studies that offer general support for this notion are scarce. In this study, we investigated long term exposures to a wide range of airborne contaminants among a broad cross section of workplaces world wide. In total, 696 sets of data were identified spanning 69 years of measurements. Our results provide clear evidence of global downward trends in exposure (far more exposures declined than increased over time), at rates which generally ranged from $-4 \%$ to $-14 \%$ per year (fig $2 \mathrm{~B}$ ). Exposures seem to have risen at lower rates than those which have declined over time. Despite the many statistical tests that were performed (which increased, for example, the probability of detecting significant trends due to chance alone), multiple testing does not seem to have invalidated our results.

Our findings also suggest that the simple log linear model described decreasing trends reasonably well (median $r^{2}=0.65$ ), but performed worse when exposures increased over time (median $r^{2}=0.11$ ). As the log-linear model seems to represent a reasonable approximation for declining exposures, model misspecification is unlikely to have presented significant problems in most cases. On the other hand, more complex models might better describe the pattern of increasing exposures and will be explored in a separate investigation.

Although only small differences were detected when the data were stratified by region or industrial sector, a greater proportion of data sets with upward trends was found for carcinogens than for non-carcinogens, and for metals than other types of contaminants (nonmetallic aerosols or vapours). Similarly, a larger proportion of exposures assessed by personal rather than biological monitoring increased over time. Effects related to calendar period and number of reductions in TLVs were found as well. Interestingly, there was almost a fourfold difference in the percentage of increasing exposures for data collected after 1972 (31\%) relative to data collected before 1972 $(8 \%)$. As expected, a smaller percentage of the data was characterised by upward trends as the number of TLV reductions increased.

Changes in air sampling and analytical methods can make it difficult to compare results obtained from different periods. Such changes were reported in about $25 \%$ of the studies, but probably underrepresent the actual figure because information about the measurement protocol was often not provided. However, differences in the precision of the estimated exposure levels throughout the sampling period (which may also have resulted from unequal numbers of measurements contributing to each mean value) should not bias our slope estimates because such unweighted least squares estimators are unbiased (assuming that the model is correct) even when the error variances are unequal. ${ }^{145}$ This lack of bias does not extend to assessments which relied on both area and personal sampling. In this instance, because measurements made with personal sampling are typically higher than those made with area samplers, ${ }^{9} 4864142$ 146-148 the estimated rates of reduction are likely to be 
smaller - that is, they are conservative-when earlier exposures were assessed by area sampling and later exposures by personal sampling. However, as relatively few data sets $(6 \%)$ fell into this category, our overall results are unlikely to have been significantly affected.

Although area sampling data will generally underestimate workers' personal exposures, the average concentration at a particular location should reflect the general work environment at a particular time and should thereby bear some relation to workers' exposures received over the same period. Thus, such data were judged to be adequate to evaluate long term trends. Although there were limited data available to compare area and personal sampling data, consistent results were obtained when such comparisons were made.

As well as errors introduced by changes in air sampling and analytical methods, the quality of the data also depends upon the sampling strategy used. As sampling strategies are often targeted toward anticipated worst case exposures, assessments of time trends may not be representative of temporal changes in average exposure levels. If assessment strategies changed during the course of a study from monitoring worst case exposures to sampling workers randomly (where the biased results are likely to have yielded higher levels than what would have been obtained had random sampling been conducted), ${ }^{2} 149150$ then it is also possible that exposures could have seemed to decline even when they remained unchanged. Unfortunately, little information about the sampling strategies was provided in most cases; so it was not possible to evaluate the part that such changes in assessment practices may have played.

It is also clear from this review that few high quality studies have been conducted to assess long term trends in exposure. Notable among our findings was the high percentage of data sets $(42 \%)$ comprised of few (three or four) observations. Although such small sample sizes may underrepresent data actually available from industrial sources, the sparseness of the published historical record can compromise the statistical power to detect trends-for example, only $31 \%$ of the data evaluated in this study showed evidence of a significant trend $(p<0.05)$. In the future, it is incumbent on occupational hygienists, who have primary responsibilities for assessing exposures, to assume a greater role in reporting such assessments in the peer reviewed literature. Changes in the work environment and the process, as well as in the methods of data collection and analysis, should also be documented.

Furthermore, the overall poor quality of the historical record, documented herein, underscores the importance of implementing more rigorous assessment practices. The arguments in favour of statistically based sampling strategies have been clearly made ${ }^{4}$ and rest largely with their use in considering a full range of questions related to overexposure, the selection of controls, the grouping of workers, and the assessment of exposure-response relations. Although such strategies take into account important random sources of variation in exposure experienced over time and between workers, the influence of temporal effects on such strategies has only recently been considered $^{6}$ and warrants further investigation.

Finally, inadequate historical data severely restrict our ability to evaluate health risks associated with occupational exposures. Although a wide variety of retrospective exposure assessment methods have been developed, ${ }^{151}$ limited options are available when few or no measurement data exist. Thus, if it were possible to measure the rates of reduction in exposure for particular contaminants in specific industries, or to identify factors that affected these rates in a consistent fashion, then statistical models could be constructed to reconstruct past exposures. Such models would greatly assist in assessing exposureresponse relations in situations where little or no historical exposure data are available.

We thank Sharon Cooper and Irva Hertz-Picciotto who reviewed the manuscript and provided helpful comments. This work was supported in part by the National Institute of Environmental Health Sciences (NIEHS) through training grant T32ES07018.

\section{Appendix: Derivation of the estimator of the median proportionate change in expo- sure per year}

Suppressing the subscripts $i$ and $j$ for notational convenience, the simple linear regression model to evaluate changes in exposure levels over time $(\mathrm{t})$ can be specified as follows:

$$
\mathrm{Y}_{\mathrm{t}}=\ln \mathrm{X}_{\mathrm{t}}=\alpha+\beta \mathrm{t}+\varepsilon_{\mathrm{t}}
$$

Under the model, $\mathrm{X}_{\mathrm{t}}$ is the mean exposure level at time $t$ and $Y_{t}$ is the $\log$ transformed value of the mean exposure level. It is assumed that $\varepsilon_{\mathrm{t}}$ is normally distributed with zero mean and variance $\sigma_{t}^{2}$ for all $t$, and that the $\left\{\varepsilon_{t}\right\}$ are mutually independent. It then follows that $\mathrm{Y}_{\mathrm{t}} \sim \mathrm{N}\left(\alpha+\beta \mathrm{t}, \sigma_{\mathrm{t}}^{2}\right)$ and that the $\left\{\mathrm{Y}_{\mathrm{t}}\right\}$ are mutually independent. Thus, $X_{t}$ has a lognormal density with $\mathrm{E}\left(\mathrm{X}_{\mathrm{t}}\right)=\mathrm{e}^{\alpha+\beta \mathrm{t}+1 / 2 \sigma^{2} \mathrm{t}}$, and the $\left\{\mathrm{X}_{\mathrm{t}}\right\}$ are mutually independent.

Now, the relative change in exposure levels

from year $t$ to year $t+1$ is $\frac{X_{t+1}-X_{t}}{X_{t}}=\frac{X_{t+1}}{X_{t}}-1$

and this is the random variable of interest. The distribution of this random variable can be determined as follows:

Since $\ln \left(\frac{X_{t+1}}{X_{t}}\right)=\ln X_{t+1}-\ln X_{t}=Y_{t+1}-Y_{t}$ where $\left(Y_{t+1}-Y_{t}\right) \sim N\left(\beta, \sigma_{t}^{2}+\sigma_{t+1}^{2}\right)$, it follows that $\frac{\mathrm{X}_{\mathrm{t}+1}}{\mathrm{X}_{\mathrm{t}}}$ is lognormal with

$E\left(\frac{X_{t+1}}{X_{t}}\right)=e^{\beta+1 / 2\left(\sigma_{t}^{2}+\sigma_{t+1}^{2}\right)}$ 
and that $\frac{\mathrm{X}_{\mathrm{t}+1}}{\mathrm{X}_{\mathrm{t}}}-1$ is also lognormal with

$E\left(\frac{X_{t+1}}{X_{t}}-1\right)=e^{\beta+1 / 2\left(\sigma_{t}^{2}+\sigma_{t+1}^{2}\right)}-1$

In our application, the median $\theta$ of the lognor-

mal density of $\frac{\mathrm{X}_{t+1}-\mathrm{X}_{t}}{\mathrm{X}_{\mathrm{t}}}$ is the parameter of

interest, and it satisfies the following relationship:

$$
\begin{aligned}
& \frac{1}{2}=\operatorname{pr}\left[\frac{\mathrm{X}_{\mathrm{t}+1}-\mathrm{X}_{\mathrm{t}}}{\mathrm{X}_{\mathrm{t}}}<\theta\right] \\
& =\operatorname{pr}\left[\mathrm{X}_{\mathrm{t}+1}<(1+\theta) \mathrm{X}_{\mathrm{t}}\right] \\
& =\operatorname{pr}\left[\ln \mathrm{X}_{\mathrm{t}+1}<\ln (1+\theta)+\ln \mathrm{X}_{\mathrm{t}}\right] \\
& =\operatorname{pr}\left[\mathrm{Y}_{\mathrm{t}+1}-\mathrm{Y}_{\mathrm{t}}<\ln (1+\theta)\right] \\
& =\operatorname{pr}\left[\frac{\left(\mathrm{Y}_{\mathrm{t}+1}-\mathrm{Y}_{\mathrm{t}}\right)-\beta}{\sqrt{\sigma_{\mathrm{t}}^{2}+\sigma_{\mathrm{t}+1}^{2}}}<\frac{\ln (1+\theta)-\beta}{\sqrt{\sigma_{\mathrm{t}}^{2}+\sigma_{\mathrm{t}+1}^{2}}}\right]
\end{aligned}
$$

Since $\frac{\left(\mathrm{Y}_{\mathrm{t}+1}-\mathrm{Y}_{\mathrm{t}}\right)-\beta}{\sqrt{\sigma_{\mathrm{t}}^{2}+\sigma_{\mathrm{t}+1}^{2}}}$ has a standard normal dis-

tribution, we must have:

$\frac{\ln (1+\theta)-\beta}{\sqrt{\sigma_{t}^{2}+\sigma_{t+1}^{2}}}=0$, or $\ln (1+\theta)=\beta$, or $\theta=e^{\beta}-1$.

The median proportionate change in exposure per year can be estimated by $\hat{\theta}=\mathrm{e}^{\beta}-1$. However, since the unweighted least squares estimator $\hat{\beta} \sim \mathrm{N}\left(\beta, \sigma_{\hat{\beta}}^{2}\right)$ when the assumed straight line model is valid, $\mathrm{E}(\hat{\theta})=\mathrm{e}^{\beta+1 / 2 \sigma^{2} \hat{\beta}}-1>\theta$. So, $\hat{\theta}$ generally tends to be less negative than desired when $\beta<0$, and it tends to be more positive than desired when $\beta>0$. In general, the bias in $\hat{\theta}$ will be small when $\sigma_{\hat{\beta}}^{2}$ is small-that is, when the number of observations is large or when $\sigma_{t}^{2}$ is small for all $\mathrm{t}$ ).

1 Esmen N. Retrospective industrial hygiene surveys. Am Ind Hyg Assoc F 1979;40:58-65.

Hyg Assoc F 1979;40:58-65.
2 Ulfvarson U. Limitations to the use of employee exposure data on air contaminants in epidemiologic studies. Int Arch data on air contaminants in epidem

3 Roach SA. Alternative ways of monitoring occupational exposure. In: Rappaport SM, Smith TJ, eds. Exposure assessment for epidemiology and hazard control. Chelsea, MI: Lewis, 1991:3-20.

4 Rappaport SM. Assessment of long-term exposures to toxic substances in air. Ann Occup Hyg 1991;35:61-121.

5 Symanski E, Rappaport SM. An investigation of the dependence of exposure variability on the interval between measurements. Ann Occup Hyg 1994;38:361-72.

6 Symanski E, Kupper LL, Kromhout H, Rappaport SM. An investigation of systematic changes in occupational exposure. Am Ind Hyg Assoc f 1996;57:724-35.

7 Chatfield C. Time series analysis: an introduction. 4th ed. London: Chapman and Hall, 1989:28-30.

8 Rappaport SM. Threshold limit values, permissible exposure limits, and feasibility: The bases for exposure limits in sure limits, and feasibility: The bases for exposure
the United States. Am f Ind Med 1993;23:683-94.

9 Adamsson E. Long-term sampling of airborne cadmium dust in an alkaline battery factory. Scand $\mathcal{f}$ Work Environ Health 1979;5:178-87.
10 Priha E, Riipinen H, Korhonen K. Exposure to formaldehyde and solvents in Finnish furniture factories in 1975-84. Ann Occup Hyg 1986;30:289-94.

11 Froines JR, Baron S, Wegman DH, et al. Characterization of the airborne concentrations of lead in US Industry. $A m \mathcal{F}$ Ind Med 1990;18:1-7.

12 Jensen AA, Breum NO, Bacher J, et al. Occupational exposures to styrene in Denmark 1955-88. Am f Ind Med 1990; 17:593-606.

13 Sällsten G, Barregård L, Järvholm B. Mercury in the Swedish chloralkali industry - an evaluation of the exposure and preventive measures over 40 years. Ann Occup Hyg 1990;34:205-14.

14 Anttila A, Sallmén M, Hemminki K. Carcinogenic chemicals in the occupational environment. Pharmacol Toxicol 1993;72(suppl 1):69-76.

15 Symanski E, Kupper LL, Hertz-Picciotto I, et al. Comprehensive evaluation of long term trends in occupational exposure: part 2. Predictive models for declining exposures. Occup Environ Med 1998;55:310-6.

16 Kromhout H, Symanski E, Rappaport SM. A comprehensive evaluation of within- and between-worker components of occupational exposure to chemical agents. Ann Occup Hyg 1993;37:253-70.

17 United Nations. International standard industrial classification of all economic activities. New York: United Nations, 1990. (Statistical papers series M, No 4, Rev 3.)

18 International Agency for Research on Cancer. Monographs on the evaluation of carcinogenic risks to humans, suppl. 7. Overall evaluations of carcinogenicity: an updating of IARC monographs 1-42. Lyon: IARC, 1987.

19 International Agency for Research on Cancer. Monographs on the evaluation of carcinogenic risks to humans. Vol 47. Lyon: IARC, 1989.

20 International Agency for Research on Cancer. Monographs on the evaluation of carcinogenic risks to humans. Vol 49. Lyon: IARC, 1990.

21 International Agency for Research on Cancer. Monographs on the evaluation of carcinogenic risks to humans. Vol 52.Lyon: IARC, 1991.

22 International Agency for Research on Cancer. Monographs on the evaluation of carcinogenic risks to humans. Vol 58. Lyon: IARC, 1993.

23 International Agency for Research on Cancer. Monographs on the evaluation of carcinogenic risks to humans. Vol 63. Lyon: IARC, 1995.

24 International Agency for Research on Cancer. Monographs on the evaluation of carcinogenic risks to humans. Vol 65. Lyon: IARC, 1996.

25 International Agency for Research on Cancer. Monographs on the evaluation of carcinogenic risks to humans. Vol 2. Lyon: IARC, Lyon, 1972.

26 International Agency for Research on Cancer. Monographs on the evaluation of carcinogenic risks to humans. Vol 11. Lyon: IARC, 1976.

27 International Agency for Research on Cancer. Monographs on the evaluation of carcinogenic risks to humans. Vol 14.Lyon: IARC, 1976.

28 International Agency for Research on Cancer. Monographs on the evaluation of carcinogenic risks to humans. Vol 20. Lyon: IARC, 1979.

29 International Agency for Research on Cancer. Monographs on the evaluation of carcinogenic risks to humans. Vol 23. Lyon: IARC, 1980.

30 International Agency for Research on Cancer. Monographs on the evaluation of carcinogenic risks to humans, suppl. 4. Chemicals, industrial processes and industries associated with cancer in humans: IARC monographs. Vol 1-29. Lyon: cancer in 1982.

31 American Conference of Governmental Industrial Hygienists. Threshold limit values: discussion and thirty five year index with recommendations (LaNier $\mathrm{ME}$, ed), Cincinnati: ACGIH, 1984

32 American Conference of Governmental Industrial Hygienists. Threshold limit values for chemical substances and physical agents and biological exposure indices, 1985-95, Cincinnati: ACGIH, 1985-95.

33 Huy T, DeSchipper K, Chan-Yeung M, et al. Grain dust and lung function. Dose-response relationships. Am Rev Respir Dis 1991;144:1314-21.

34 Dewell P. Concentrations of cadmium in air and urine in an alkaline battery works. Ann Occup Hyg 1994;38:209-18.

35 Hallock MF, Smith TJ, Woskie SR, et al. Estimation of historical exposures to machining fluids in the automotive torical exposures to machining fluids in
industry. Am f Ind Med 1994;26:621-34.

36 Ferris BG, Burgess WA, Worcester J. Prevalence of chronic respiratory disease in a pulp mill and a paper mill in the United States, Brf Ind Med 1967;24:26-37.

37 Gibbs GW, Lachance M. Dust exposure in the chrysotile asbestos mines and mills of Quebec. Arch Environ Health 1972;24:189-97.

38 Kaltreider NL, Elder MJ, Cralley LV, et al. Health survey of aluminum workers with special reference to fluoride exposure. 7 Occup Med 1972;14:531-41.

39 Raleigh RL, McGee WA. Effects of short, high concentration exposures to acetone as determined by observation in the work area. 7 Occup Med 1972;14:607-10.

40 Kleinfeld M, Messite J, Langer AM. A study of workers exposed to asbestiform minerals in commercial talc manufacture. Environ Res 1973;6:132-42.

41 Kleinfeld M, Messite J, Zaki MH. Mortality experiences among talc workers: a follow-up study. F Occup Med 1974; 16:345-49. 
42 Theriault GP, Burgess WA, DiBerardinis LJ, et al. Dust exposure in the Vermont granite sheds. Arch Environ Health 1974;28:12-7.

43 Dinman BD, Elder MJ, Bonney TB, et al. Prevention of bony fluorosis in aluminum smelter workers. A 15-year retrospective study of fluoride excretion and bony radiopacity among aluminum smelter workers - Pt 4. f Occup Med 1976;18:21-5.

44 Smith TJ, Wagner WL, Moore DE. Chronic sulfur dioxide exposure in a smelter. I. Exposure to SO2 and dust: 194074. F Occup Med 1978;20:83-7.

45 Lewinsohn HC, Kennedy CA, Day JE, et al. Dust control in a conventional asbestos textile factory. Ann NY Acad Sci 1979;330:225-41.

46 Parobeck PS, Jankowski RA. Assessment of the respirable dust levels in the nation's underground and surface coal mining operations. Am Ind Hyg Assoc f 1979;40:910-15.

47 Currier MF, McClimans CD, Barna-Lloyd G. Hexachlorobenzene blood levels and the health status of men employed in the manufacture of chlorinated solvents. $f$ Toxicol Environ Health 1980;6:367-77.

48 Smith TJ, Anderson RJ, Reading JC. Chronic cadmium exposures associated with kidney function effects. Am $\mathcal{F}$ Ind Med. 1980;1:319-37.

49 Rinsky RA, Young RJ, Smith, AB. Leukemia in benzene workers. Am f Ind Med 1981;2:217-45.

50 Enterline PE, Marsh GP. Cancer among workers exposed to arsenic and other substances in a copper smelter. Am $\mathcal{F} E p i-$ demiol 1982;116:895-911.

51 Gartside PS, Buncher CR, Lerner S. Relationship of air lead and blood lead for workers at an automobile battery factory. Int Arch Occup Environ Health 1982;50:1-10.

52 McGrath KG, Roach D, Zeiss CR, et al. Four-year evaluation of workers exposed to trimellitic anhydride. A evaluation of workers exposed to trimellitic
brief report. $\mathcal{F}$ Occup Med. 1984;26:671-5.

53 Baker EL, White RF, Pothier LJ, et al. Occupational lead neurotoxicity: improvement in behavioural effects after reduction of exposure. $\mathrm{Br}$ f Ind Med 1985;42:507-16.

54 Gee JB, Morgan WKC. A 10 -year follow-up study of a group of workers exposed to isocyanates. $\mathcal{F}$ Occup Med 1985;27:15-8.

55 Thun MJ, Baker DB, Steenland K, et al. Renal toxicity in uranium mill workers. Scand $\mathcal{f}$ Work Environ Health 1985;11:83-90.

56 Keimig DG, Slymen DJ, White O. Occupational exposure to coke oven emissions from 1979-83. Arch Environ Health 1986;41:363-7.

57 Amandus HE, Wheeler R, Jankovic J, et al. The morbidity and mortality of vermiculite miners and millers exposed to tremolite-actinolite: Part I. Exposure estimates. Am f Ind Med. 1987;11:1-14

58 Hearne FT, Grose F, Pifer JW, et al. Methylene chloride mortality study: dose-response characterization and anima model comparison. f Occup Med 1987;29:217-28.

59 Kriebel D, Sprince NL, Eisen EA, et al. Pulmonary function in beryllium workers: assessment of exposure. $\mathrm{Br} \mathcal{f}$ Ind $\mathrm{Med}$ 1988;45:83-92.

60 McDonald JC, McDonald AD, Sébastien P, et al. Health of vermiculite miners exposed to trace amounts of fibrous tremolite. Br f Ind Med 1988;45:630-4.

61 Collins JJ, Page LC, Caporossi JC, et al. Mortality patterns among men exposed to methyl methacrylate. $\mathcal{F}$ Occup Med 1989;31:41-6.

62 Henneberger PK, Eisen EA, Ferris BG. Pulmonary function among pulp and paper workers in Berlin, New Hampshire. $B r$ F Ind Med 1989;46:765-72.

63 Kononen DW, Kintner HJ, Bivol KR. Air lead exposures and blood lead levels within a large automobile manufacturing workforce, 1980-5. Arch Environ Health 1989;44: 244-51.

64 Roy ML, Siu S, Waddell W, et al. Worker exposure to lead titanate zirconate in an Ontario company. 7 Occup Med 1989;31:986-9.

65 Piacitelli GM, Amandus HE, Dieffenback A. Respirable dust exposures in US surface coal mines (1982-6). Arch dust exposures in US surface
Environ Health 1990;45:202-9.

66 Bond GG, Flores GH, Stafford BA, et al. Lung cancer and hydrogen chloride exposure: results from a nested casecontrol study of chemical workers. F Occup Med 1991;33 958-61.

67 Hodgkins DG, Robins TC, Hinkamp DL, et al. A longitudinal study of the relation of lead in blood to lead in air concentrations among battery workers. Br f Ind Med 1992;49: 241-8.

68 Nelson NA, Robins TG, Garrison RP, et al. Historical characterization of exposure to mixed solvents for an epidemoacterization of exposure to mixed solvents for an epidemologic study of automotive assembly
Occup Environ Hyg 1993;8:693-702.

69 Pifer JW, Hearne FT, Swanson FA, et al. Mortality study of employees engaged in the manufacture and use of hydroquinone. Int Arch Occup Environ Health 1995;67: 267-80.

70 Watts WF, Parker DR. Quartz exposure trends in metal and nonmetal mining. Appl Occup Environ Hyg 1995;10:100918.

71 Berry G, Lewinsohn HC. Dose-response relationships for asbestos-related disease: implications for hygiene standards. Part I. Morbidity. Ann NY Acad Sci 1979;330:18594.

72 Stewart $M$, Hughes EG. Urinary $\beta_{2}$ microglobulin in the biological monitoring of cadmium workers. $\mathrm{Br} F$ Ind $\mathrm{Med}$ 1981;38:170-4.
73 Craw J. Pneumoconiosis in the haematite iron ore mines of west Cumbria. A study of 45 years of control. 7 Soc Occup Med 1982;32:53-65.

74 Crawford NP, Bodsworth PL, Hadden GG, et al. A study of apparent anomalies between dust levels and pneumoconiosis at British collieries. Ann Occup Hyg 1982;26:725-44.

75 Bodel CC, McAulay IR. Dust levels in flax mills in Northern Ireland 1961-81. Ann Occup Hyg 1983;27:359-66.

76 Thomas JD, Wilson HK. Biological monitoring of workers exposed to 4,4'-methylenebis (2-chloroaniline) (MBOCA). Br F Ind Med 1984;41:547-51.

77 Marcus RL. Investigation of a working population exposed to thallium. F Soc Occup Med 1985;35:4-9.

78 Peto J, Doll R, Hermon C, et al. Relationship of mortality to measures of environmental asbestos pollution in an asbestos textile factory. Ann Occup Hyg 1985;29:305-55.

79 Gardner MJ, Winter PD, Pannett B, et al. Follow up study of workers manufacturing chrysotile asbestos cement prodworkers manufacturing chrysotile as

80 Ide CW, Bullough GR. Arsenic and old glass. F Soc Occup Med 1988:38:85-8.

81 Mason HJ, Davison AG, Wright AL, et al. Relations between liver cadmium, cumulative exposure, and renal function in cadmium alloy workers. Br f Ind Med 1988;45:793-802.

82 Nunn AJ, Craigen AA, Darbyshire JH, et al. Six year follow up of lung function in men occupationally exposed to formaldehyde. Br F Ind Med 1990;47:747-52.

83 Adams RG. Manufacturing process, resultant risk profiles and their control in the production of nickel-cadmium (alkaline) batteries. Occup Med 1992;42:101-6.

84 Kogevinas M, Ferro G, Andersen A, et al. Cancer mortality in a historical cohort study of workers exposed to styrene. Scand $\mathcal{F}$ Work Environ Health 1994;20:251-61.

85 Tolonen M, Hernberg S, Nurminen M, et al. A follow-up study of coronary heart disease in viscose rayon workers study of coronary heart disease in viscose rayon workers

86 Roto P. Urinary $\beta_{2}$ microglobulin related to chronic low level exposure to metallic cadmium dust in Finnish cadmium processing workers. Scand $\mathcal{F}$ Work Environ Health $1978 ; 4: 131-6$

87 Hernberg S, Tola S. The battle against occupational lead poisoning in Finland. Experiences during the 15-year period 1964-78. Scand $\mathcal{F}$ Work Environ Health 1979;5:33644.

88 Hogstedt C, Davidsson B. Nitroglycol and nitroglycerine exposure in a dynamite industry 1958-78. Am Ind Hyg Assoc f 1980;41:373-75.

89 Roto P. Asthma, symptoms of chronic bronchitis and ventilatory capacity among cobalt and zinc production workers. Scand $\mathcal{F}$ Work Environ Health 1980;6(suppl 1):6-49.

90 Högstedt B, Akesson B, Axell K, et al. Increased frequency of lymphocyte micronuclei in workers producing reinforced polyester resin with low exposure to styrene. Scand $\mathcal{F}$ Work Environ Health 1983;9:241-6.

91 Nurminen M, Hernberg S. Effects of intervention on the cardiovascular mortality of workers exposed to carbon disulphide: 15 year follow up. Br F Ind Med 1985;42:32-5.

92 Simonsson BG, Sjöberg A, Rolf C, et al. Acute and long-term airway hyperreactivity in aluminum-salt exposed workers with nocturnal asthma. Eur $\mathcal{F}$ Respir Dis 1985;66: $105-18$

93 Hagmar L, Arborelius M, Bellander T, et al. Small airways unction in workers exposed to piperazine. Int Arch Occup Environ Health 1987;59:521-8.

94 Gregersen P. Neurotoxic effects of organic solvents in exposed workers: two controlled follow-up studies after 5.5 and 10.6 years. Am F Ind Med 1988;14:681-701.

95 Flodin U, Ekberg K, Andersson L. Neuropsychiatric effects of low exposure to styrene. Br f Ind Med 1989;46:805-8.

96 Hagmar L, Högstedt B, Welinder H, et al. Cytogenetic and hematological effects in plastics workers exposed to styrene. Scand $\mathcal{F}$ Work Environ Health 1989;15:136-41.

97 Tuominen M, Tuominen R, Ranta K, et al. Association between acid fumes in the work environment and dental erosion. Scand $\mathcal{F}$ Work Environ Health 1989;15:335-8

98 Albin M, Jakobsson K, Attewell R, et al. Mortality and cancer morbidity in cohorts of asbestos cement workers and referents. Br f Ind Med 1990;47:602-10.

99 Svensson BG, Nise G, Englander V, et al. Deaths and tumours among rotogravure pr

100 Ahlman K, Koskela R-S, Kuikka P, et al. Mortality among sulfide ore miners. Am f Ind Med 1991;19:603-17.

101 Hagmar L, Welinder $\mathrm{H}$, Lindén $\mathrm{K}$, et al. An epidemiological study of cancer risk among workers exposed to ethylene oxide using hemoglobin adducts to validate environmental exposure assessments. Int Arch Occup Environ Health 1991; 63:271-7.

102 Kongerud J, Samuelsen SO. A longitudinal study of respiratory symptoms in aluminum potroom workers. Am Rev Respir Dis 1991;144:10-6.

103 Fandrem SI, Kjuus H, Andersen A, et al. Incidence of cancer among workers in a Norwegian nitrate fertiliser plant. Br f Ind Med 1993;50:647-52.

104 Gerhardsson L, Attewell R, Chettle DR, et al. In vivo measurements of lead in bone in long-term exposed lead smelter workers. Arch Environ Health 1993;48:147-56.

105 Hansen J, Schneider T, Olsen JH, et al. Availability of data on humans potentially exposed to suspected carcinogens in
the Danish working environment. Pharmacol Toxicol 1993; 72(suppl 1):77-85.

106 Jakobsson K, Horstmann V, Welinder H. Mortality and cancer morbidity among cement workers. $\mathrm{Br} \mathcal{F}$ Ind $\mathrm{Med}$ 1993;50:264-72. 
107 Bast-Pettersen R, Drablos PA, Goffeng LO, et al. Neuropsychological deficit among elderly workers in aluminum production. Am f Ind Med 1994;25:649-62.

108 Christensen JM, Poulsen OM. A 1982-92 surveillance programme on Danish pottery painters. Biological levels and health effects following exposure to soluble or insoluble cobalt compounds in cobalt blue dyes. Sci Total Environ 1994;150:95-104.

109 Nordhagen HP, Ellingsen DG, Kjuus H. Production and surveillance of mercury exposure over 40 years at a chloralkali plant. Ann Occup Hyg 1994;38:777-88.

110 Pekari K. Occupational exposure to benzene, toluene and styrene in Finland as estimated by biological monitoring. Occup Hyg 1994;1:95-117.

111 Soyseth V, Kongerud J, Ekstrand J, et al. Relation between exposure to fluoride and bronchial responsiveness in aluminium potroom workers with work-related asthma-like symptoms. Thorax 1994;49:984-9.

112 Gerhardsson L, Hagmar L, Rylander L, et al. Mortality and cancer incidence among secondary lead smelter workers. Cancer incidence among secondary

113 Balcarová O, Halík J. Ten-year epidemiological study of schaemic heart disease (IHD) in workers exposed to carbon disulphide. Sci Total Environ 1991;101:97-9.

114 Krampl V, Suchánek P, Doupovcová M. A study of occupational exposure to isopropylbiphenyls (SURE SOL250). Sci Total Environ 1991;101:135-8.

115 Gowers DS, DeFonso LR, Schaffer P, et al. Incidence of respiratory cancer among workers exposed to chloromethyl-ethers. Am F Epidemiol 1993;137:31-42.

116 Kentner M, Fischer T, Richter G. Changes in external and internal lead load in different working areas of a starter battery production plant in the period 1982 to 1991 . Int Arch Occup Environ Health 1994;66:23-31.

117 Rubino GF, Scansetti,G, Piolatto G, et al. Mortality study of talc miners and millers. F Occup Med 1976;18:186-93.

118 Franchini I, Magnani F, Mutti A. Mortality experience among chromeplating workers. Initial findings. Scand $\mathcal{F}$ among chromeplating workers. Inital

119 Soleo L, Urbano ML, Petrera V, et al. Effects of low exposure to inorganic mercury on psychological performance. sure to inorganic mercury on
$B r f$ Ind Med 1990;47:105-9.

120 Foa V, Ferioli A. The microdose problem and the most commonly used metals. Sci Total Environ 1992;120:11725.

121 Alessio L, Apostoli P, Forni A, et al. Biological monitoring of cadmium exposure-an Italian experience. Scand 7 Work Environ Health 1993;19(suppl 1):27-33.

122 Galassi C, Kogevinas M, Ferro G, et al. Biological monitoring of styrene in the reinforced plastics industry in Emilia Romagna, Italy. Int Arch Occup Environ Health 1993;65:89-95.

123 Vertin PG. Incidence of cardiovascular diseases in the Dutch viscose rayon industry. $\mathcal{F}$ Occup Med 1978;20:34650 .

124 Boogaard PJ, Rocchi PSJ, van Sittert NJ. Effects of exposure to low concentrations of chlorinated hydrocarexposure to low concentrations of chlorinated hydrocarMed 1993;50:331-9.

125 van Sittert NJ, Ribbens PH, Huisman B, et al. A nine year follow up study of renal effects in workers exposed to cadmium in a zinc ore refinery. Brf Ind Med 1993;50:603-12.

126 Boogaard PJ, van Sittert NJ. Exposure to polycyclic aromatic hydrocarbons in petrochemical industries by measurement of urinary 1-hydroxypyrene. Occup Environ Med 1994;51:250-8.

127 Studniarek M, Durski K, Liniecki J, et al. Effects of vinyl chloride on liver function of exposed workers, evaluated by measurements of plasma clearance of the $99 \mathrm{~m}_{\mathrm{Tc}} \mathrm{N}-2$, 4-dimethylacetanilido-iminodiacetate complex. If Appl Toxicol 1989;9:213-8.

128 Suciu I, Prodan L, Ilea E, et al. Clinical manifestations in vinyl chloride poisoning. Ann NY Acad Sci 1975;246:53-
129 Tolonen M, Hernberg S, Nordman C-H, et al. Angina pectoris, electrocardiographic findings and blood pressure in Finnish and Japanese workers exposed to carbon disulfide. Int Arch Occup Environ Health 1976;37:249-64.

130 Tsuchiya K. Proteinuria of cadmium workers. f Occup Med 1976;18:463-6.

131 Sato K, Fujita $\mathrm{H}$, Inui $\mathrm{S}$, et al. Changes in urinary $\delta$-aminolevulinic acid at low lead exposure level with special reference to production activity. Int Arch Occup Environ Health 1983;52:25-32.

132 Kishi R, Harabuchi I, Katakura Y, et al. Neurobehavioral effects of chronic occupational exposure to organic solvents among Japanese industrial painters. Environ Res 1993;62: 303-13.

133 Sakai T, Kageyama H, Araki T, et al. Biological monitoring of workers exposed to N,N-dimethylformamide by determination of the urinary metabolites, N-methylformamide mination of the urinary metabolites, N-methylformamide Occup Environ Health 1995;67:125-9.

134 Wang Y-L. Industrial lead poisoning in China over the past 33 years. Ecotoxicol Environ Saf 1984;8:526-30.

135 Liang Y-X, Qu D-Z. Cost-benefit analysis of the recovery of carbon disulfide in the manufacturing of viscose rayon. Scand $\mathcal{F}$ Work Environ Health 1985;11(suppl 4):60-3.

$136 \mathrm{Hu} \mathrm{X}, \mathrm{Lu} \mathrm{Y}$, Xue S, et al. Toxicity of dipterex: a field study. Br f Ind Med 1986;43:414-9.

137 Li J, Jiang Q-G, Zhong W-D. Persistent ethanol drinking increases liver injury induced by trinitrotoluene exposure: an in-plant case-control study. Hum Exp Toxicol 1991;10: 405-9.

138 Dosemeci M, Li G-L, Hayes RB, et al. Cohort study among workers exposed to benzene in China: II. Exposure assessment. Am f Ind Med 1994;26:401-11.

139 Dosemeci M, McLaughlin JK, Chen J-Q, et al. Historical total and respirable silica dust exposure levels in mines and pottery factories in China. Scand 7 Work Environ Health 21 1995;21 (suppl 2):39-43.

140 Niu Q, Liu T, Li T, et al. Coal workers' pneumoconiosis and related risk indices. $\mathcal{F}$ Occup Health 1996;38:82-8.

141 Chia SE, Foo SC, Gan SL, et al. Neurobehavioral functions among workers exposed to manganese ore. Scand 7 Work Environ Health 1993;19:264-70.

142 Dossing M, Paulev P-E. Blood- and air-lead concentrations during five years of occupational exposure: the effectiveness of an occupational hygiene programme and problems due to welding operations. Ann Occup Hyg 1983;27: $367-72$.

43 Sharon A. Dust levels in an asbestos-cement factory: problem-solving. Am f Ind Med 1986;10:533-7.

144 Sluis-Cremer GK. Asbestosis in South African asbestos miners. Environ Res 1970;3:310-9.

145 Neter J, Wasserman W, Kutner MH. Applied linear statistical models, 2nd ed. Homewood, IL: Richard D Irwin, 1985.

146 Linch AL, Wiest EG, Carter MD. Evaluation of tetraalkyl lead exposure by personnel monitor surveys. Am Ind Hyg Assoc F 1970;31:170-7

47 Siltanen E, Koponen M, Kokko A, et al. Dust exposure in Finnish foundries. Scand f Work Environ Health 1976; 2(suppl 1):19-31.

148 Zock J-P, Heederik D, Kromhout H. Exposure to dust, endotoxin and micro-organisms in the potato processing industry. Ann Occup Hyg 1995;39:841-5.

149 Olsen, E, Laursen, B, Vinzents PS. Bias and random errors in historical data of exposure to organic solvents. Am Ind Hyg Assoc f 1991;52:204-11.

50 Olsen, E. Effect of sampling on measurement errors. Analyst 1996;121:1155-61.

151 Seixas NS, Checkoway H. Exposure assessment in industry specific retrospective occupational epidemiology studies. Occup Environ Med 1995;52:625-33. 